\title{
Assessing the effect of indoor environmental quality on productivity at office work
}

\author{
Zdenka Budaiova, Silvia Vilcekova \\ Technical University of Košice, Slovakia \\ Civil Engineering Faculty, Institute of Environmental Engineering \\ e-mail: zdenka.budaiova@tuke.sk, silvia.vilcekova@ tuke.sk
}

\begin{abstract}
In a real environment makes it very difficult to evaluate the effect of a single parameter on human productivity, mostly because many of them are present at the same time and act together on each occupant. This study is aimed at investigation of selected office building to determine the presence of polluting agents such as volatile organic compounds, particulate matters and carbon dioxide and to assess the perceived productivity by office occupants. Occupants performed simulated office work consisting of three tasks in three office spaces. The mean values of total volatile organic compounds were in line with those found in other studies; taking into account the guideline value suggested by Molhave $\left(200 \mu \mathrm{g} \cdot \mathrm{m}^{-3}\right)$. Mean values of $\mathrm{PM}_{10}$ mass concentrations exceeded the indoor limit value $\left(50 \mu \mathrm{g} . \mathrm{m}^{-3}\right)$ by $62.7 \%$ in office 1 and by $46.49 \%$ in reception. Concentrations of carbon dioxide in monitored office spaces were under the recommended concentration according to Pettenkofer (1800 mg. $\left.\mathrm{m}^{-3}\right)$.
\end{abstract}

Key words: office, indoor environment, perceived productivity, occupants

\section{Introduction}

It is widely accepted that the indoor environmental quality is important for public health and that a high level of protection against adverse health effects due to inadequate quality of the indoor environment should be assured [1]. The human right to a healthy indoor environment includes the right to breathe clean air [2], the right to thermal comfort, and the right to visual health and visual comfort [3, 4]. The effect of lighting on vision is most obvious impact of light on humans. Lighting conditions can also affect human performance through the circadian system. There can be no guarantee that daylight will always be successful in maximizing visual performance. People will take action to reduce or eliminate daylight i fit causes discomfort or increases task difficulty [5]. Field studies have shown that a higher ventilation rate reduces the proportion of people dissatisfied with the perceived air quality in office buildings [3, 4]. Air-conditioned office buildings are aimed to provide an acceptable indoor air quality for human comfort and work that would in turn enable better productivity 
and less thermal dissatisfaction [1]. Galasiu and Veitch defined acoustic comfort as "a state of contentment with acoustic conditions". However, the term acoustic comfort is not commonly used and providing a good acoustic environment is mainly associated with preventing the occurrence of discomfort (annoyance) [6]. Noise is more difficult to adjust because it is often not under control, especially in working conditions [7]. In another study also investigating the effects of draught and window area, it was found that for a warm environment a $1{ }^{\circ} \mathrm{C}$ decrease in operative temperature led to the same decrease in annoyance as a $7 \mathrm{~dB}$ noise level decrease [8]. In existing and future buildings there will be an increasing focus on energy uses and indoor environmental quality. Energy consumption of buildings depends significantly on the criteria used for the indoor environment (temperature, ventilation and lighting) and building design and operation [9].

Measurement of performance is the process of collecting, analyzing and/or reporting information regarding the performance of an individual, group, organization, system or component [10]. Productivity is one of the key factors that define a company's ability to thrive in competition [11].

In study of Toftum et al. has led to the development - and the first field application - of a new method to assess indoor environmental quality in office buildings and to measure effects on health, comfort and work productivity of their occupants. The procedure comprises measurements of environmental parameters, including - but not limited to - thermal parameters, IAQ, $\mathrm{CO}_{2}$ and completion by occupants of on-line questionnaires [12].

This paper presents the results from measuring the indoor environmental parameters in different office spaces. Indoor environmental quality conditions were determined by continuous measurements, while the building occupants' satisfaction with environmental attributes was surveyed simultaneously. Occupants' productivity was tested also in this study.

\section{Methods - case study}

Monitoring of indoor environmental quality carried out in three rooms (two offices and one reception) on the $1^{\text {st }}$ floor of office building located in city of Kosice, the Slovak Republic (Figure 1). A more detailed description of the building can be found in Table 1. Measurements of thermal parameters, $\mathrm{CO}_{2}$, illuminance and noise were realised during heating season in 2014. Experimental measurements were conducted for three days; each day for 6 hours during operation of building. Schema of research work procedure is described in Figure 2.

The area dimensions of offices (O1 and $\mathrm{O} 2)$ representing closed office rooms were approximately the same; floor surface of room was about $25 \mathrm{~m}^{2}$. The area dimensions of reception were about $36 \mathrm{~m}^{2}$. The windows in these rooms were oriented to the road with heavy traffic. All offices' walls were covered by plaster and painting. The offices were equipped by personal computers, printers, photocopy machines, further furniture, chairs and tables. Two office rooms were covered with carpets made of synthetic material; space of reception was covered with floor tiles. 

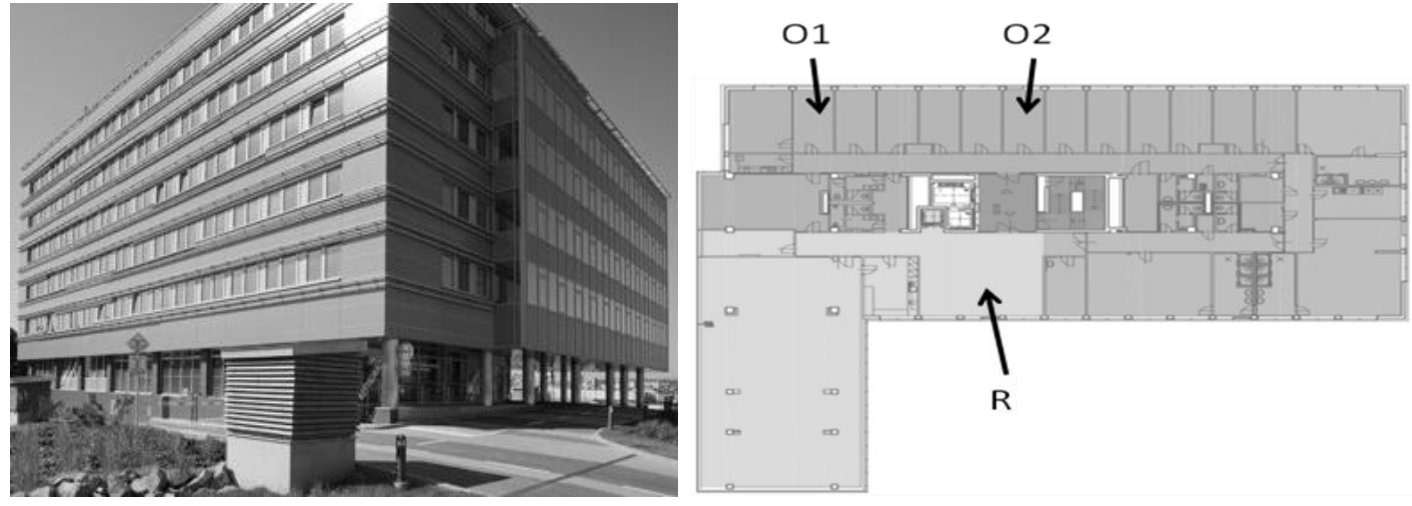

Figure 1: Photo of monitored building and floor plan

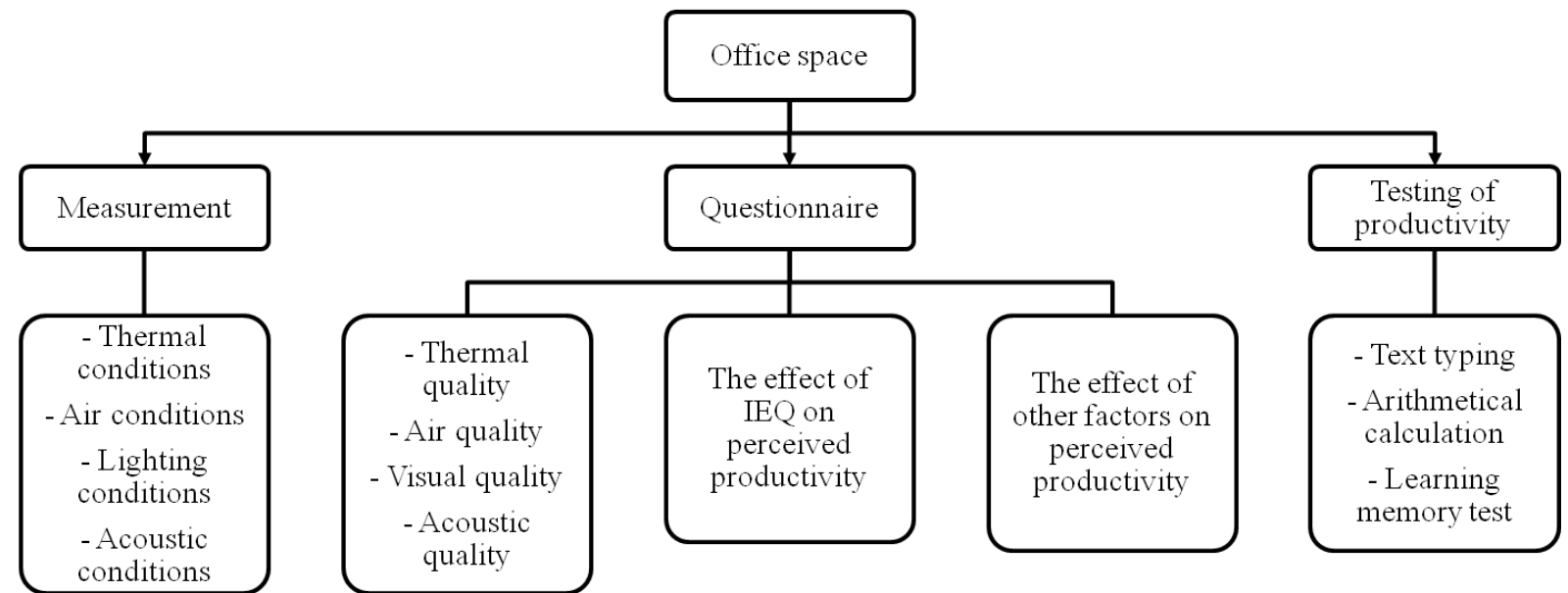

Figure 2: Schema of research work procedure

Table 1: Characteristics of office building investigated

\begin{tabular}{|c|c|}
\hline Aspect & Monitored building \\
\hline Construction year & $10500 \mathrm{~m}^{2}$ \\
\hline Floor surface & 6 \\
\hline Number of floors & $\begin{array}{c}\text { Mechanical supply and exhaust system, } \\
\text { operable windows }\end{array}$ \\
\hline Ventilation system & $\begin{array}{c}\text { Slab heating connected to geothermal } \\
\text { installation with heat pump }\end{array}$ \\
\hline Heating system
\end{tabular}

There were two women in the office $1(\mathrm{O} 1)$, one woman in the office $2(\mathrm{O} 2)$ and one woman in reception desk $(\mathrm{R})$ during the measurements. 


\subsection{Measurements}

Environmental conditions, air temperature, relative humidity, carbon dioxide $\left(\mathrm{CO}_{2}\right)$, total volatile organic compounds (TVOC) and particulate matters (PM) were recorded at oneminute intervals for three days in the middle of the experimental rooms. Indoor air temperature, relative humidity and $\mathrm{CO}_{2}$ levels in the office spaces were measured continuously by multiple-function measuring instrument Testo 435. Air velocity was measured by anemometer Testo 425. Illuminance level was measured occasionally at each workstation by multiple-function measuring instrument Testo 435. The noise level was measured occasionally at each workstation, using sound-level meter Brüel \& Kjaer type 2250. PM concentrations were measured continuously through the experiment at five stands in the office space with HANDHELD airborne particle counter 3016. Concentrations of TVOC in the office spaces were measured with the photo ionization detector ppbRAE 3000 (re-counted on toluene). Instruments were located approx. in the middle of the office spaces at $1.1 \mathrm{~m}$ defined as the "breathing zone". Globe temperature was measured at three heights $0.1,1.1$ and $1.7 \mathrm{~m}$ above the floor in the middle of the experimental office spaces with the Vernon-Jokl globe thermometer. The data were recorded every $15 \mathrm{~min}$. during the experiment. Finally the operative temperature was calculated.

\subsection{Questionnaires}

The questionnaire included questions regarding general perceptions of the environment, emotion, and self estimate productivity. Different types of evaluation scales were used in questionnaires [13]:

- scale of sensation evaluation (0 comfort, 1 slight discomfort, 2 discomfort, 3 very discomfort);

- scale for self-evaluation of productivity (3 greatly increases, 2 increases, 1 slight increases, 0 neutral, -1 slight decreases, -2 decreases, -3 greatly decreases);

- scale for overall evaluation (more acceptable than unacceptable, more unacceptable than acceptable; 0 very well tolerable, 1 well tolerable, 2 quite tolerable, 3 difficult tolerable, 4 intolerable).

\subsection{Testing of productivity}

During exposure, occupants performed simulated office work consisting of text typing, arithmetical calculation (addition) and learning memory test (assign a symbol to the correct letter). Occupants typed Slovak sentences from popular magazine for $5 \mathrm{~min}$ for the text typing activity. Addition task was a 5-min calculation task of 2-digit numbers added together. The test included a total of 35 items. Symbol-letter modalities test was a learning memory test. Eight symbols and letters were paired. Each occupant was instructed to type the letter keys to corresponding symbols. The test included a total of 108 items.

\section{Results and discussion}

The measured values of indoor environmental parameters were compared by limit values according to Slovak legislative. Limit values of physical and chemical factors are determined 
by Decree of the Ministry of Health of the Slovak Republic No. 259/2008 Coll. and Government Ordinance SR No. 115/2006 Coll. [14, 15].

The air temperatures ranged from $20.0^{\circ} \mathrm{C}$ to $24.6^{\circ} \mathrm{C}$ in the monitored office room $\mathrm{O} 1$ with a mean value of $24.2^{\circ} \mathrm{C}$. The air temperatures ranged from $22.1^{\circ} \mathrm{C}$ to $25.1^{\circ} \mathrm{C}$ in the monitored office room $\mathrm{O} 2$ with a mean value of $24.8^{\circ} \mathrm{C}$. The air temperatures ranged from $22.3^{\circ} \mathrm{C}$ to $24.8^{\circ} \mathrm{C}$ in the monitored room $\mathrm{R}$ with a mean value of $24.0^{\circ} \mathrm{C}$. The measured relative air humidity ranged from $30.3 \%$ to $40.2 \%$ with a mean value of $33.7 \%$ in the monitored rooms. The operative temperature wasn't exceeded permissible limit (ranged from $20^{\circ} \mathrm{C}$ to $24^{\circ} \mathrm{C}$ ) in monitored three rooms (Decree of the Ministry of Health of the Slovak Republic No. 259/2008 Coll.) [14].

In office $\mathrm{O} 1$ the maximum concentration of carbon dioxide $\left(\mathrm{CO}_{2}\right)$ reached value of 1893 $\mathrm{mg} . \mathrm{m}^{-3}$ and mean value was $1582 \mathrm{mg} \cdot \mathrm{m}^{-3}$. In office $\mathrm{O} 2$ the maximum concentration of $\mathrm{CO}_{2}$ reached value of $1742 \mathrm{mg} \cdot \mathrm{m}^{-3}$ and averaged $1439 \mathrm{mg} \cdot \mathrm{m}^{-3}$. In reception $\mathrm{R}$ the maximum concentration of $\mathrm{CO}_{2}$ reached $1783 \mathrm{mg} \cdot \mathrm{m}^{-3}$ and mean value was $1780 \mathrm{mg} \cdot \mathrm{m}^{-3}$. Concentrations of $\mathrm{CO}_{2}$ in monitored office spaces were under the recommended concentration according to Pettenkofer (1800 mg.m $\left.{ }^{-3}\right)$ [16].

Mean values of illuminance level were $680 \mathrm{~lx}$ in $\mathrm{O} 1 ; 553 \mathrm{~lx}$ in $\mathrm{O} 2$ and $590 \mathrm{~lx}$ in R. Mean value of sound pressure level was $52 \mathrm{~dB}$ in $\mathrm{O} 1 ; 47 \mathrm{~dB}$ in $\mathrm{O} 2$ and $51 \mathrm{~dB}$ in R. Measured value of illuminance level were fulfilled (Decree No. 259/2008 Coll.) [10], the measured sound pressure level were exceeded limit values in $\mathrm{O} 1$ and in $\mathrm{R}$ according to Slovak legislative (Government Ordinance SR No. 115/2006 Coll.) [15].

The highest PM concentrations were found in room O1 for total PM and for particle size fractions - $\mathrm{PM}_{5.0}$ and $\mathrm{PM}_{10.0}$. This finding might confirm the significance of the outdoor PM sources because the windows in office $\mathrm{O} 2$ were closed during the measurement while the windows in rooms $\mathrm{O} 1$ and $\mathrm{R}$ were several times opened during the sampling. Concentrations of the particulate matter measured in the monitored office spaces are presented in Table 2 . The measured values of $\mathrm{PM}_{10}$ were compared with the limit value according to Decree of the Ministry of Health of the Slovak Republic No. 259/2008 [14]. The limit value for $\mathrm{PM}_{10}$ indoor concentration $\left(50 \mu \mathrm{g} . \mathrm{m}^{-3}\right)$ was exceeded in two rooms.

Table 2: Mean value of particulate mass concentrations in office spaces

\begin{tabular}{|c|c|c|c|c|c|c|}
\hline \multirow{2}{*}{$\begin{array}{c}\text { Office } \\
\text { spaces }\end{array}$} & \multicolumn{5}{|c|}{ Particulate mass concentrations $\left[\mu \mathrm{g} . \mathrm{m}^{-3}\right]$} \\
\cline { 2 - 7 } & $\mathrm{PM}_{0.5}$ & $\mathrm{PM}_{1.0}$ & $\mathrm{PM}_{2.5}$ & $\mathrm{PM}_{5.0}$ & $\mathrm{PM}_{10.0}$ & Total PM \\
\hline $\mathrm{O} 1$ & 6.17 & 9.64 & 13.94 & 44.67 & 81.35 & 90.87 \\
\hline $\mathrm{O} 2$ & 5.52 & 7.38 & 8.73 & 21.66 & 39.22 & 44.43 \\
\hline $\mathrm{R}$ & 11.87 & 19.92 & 22.52 & 42 & 73.18 & 80.36 \\
\hline
\end{tabular}

Courses of total particulate mass concentrations are illustrated in Figure 4. There were noticed the increase in concentrations of particles in $\mathrm{O} 1$ and in $\mathrm{R}$ when the windows were opened. The concentrations of PM were lower in these two rooms when the windows were closed. 


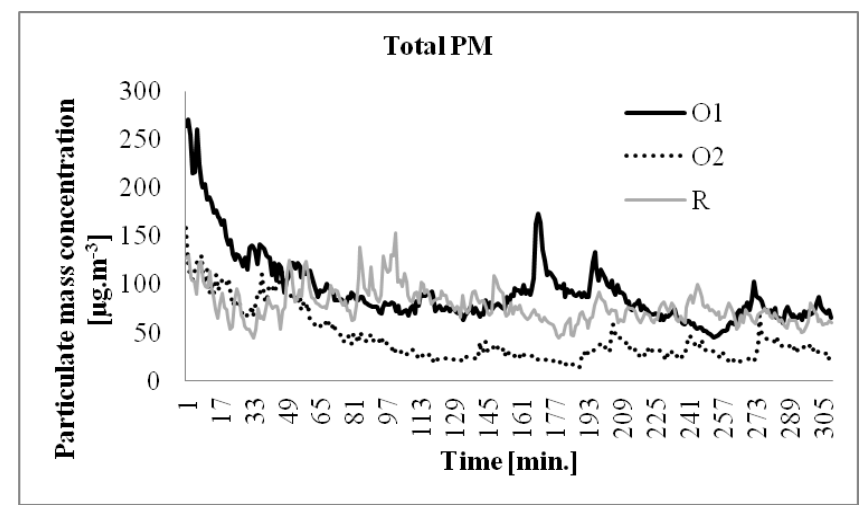

Figure 4: Course of total particulate mass concentrations in monitored rooms

The PM particle size fractions were less, the particulate number concentrations were higher. Number concentrations of PM for each measured fraction in investigated spaces are illustrated in Figure 5.

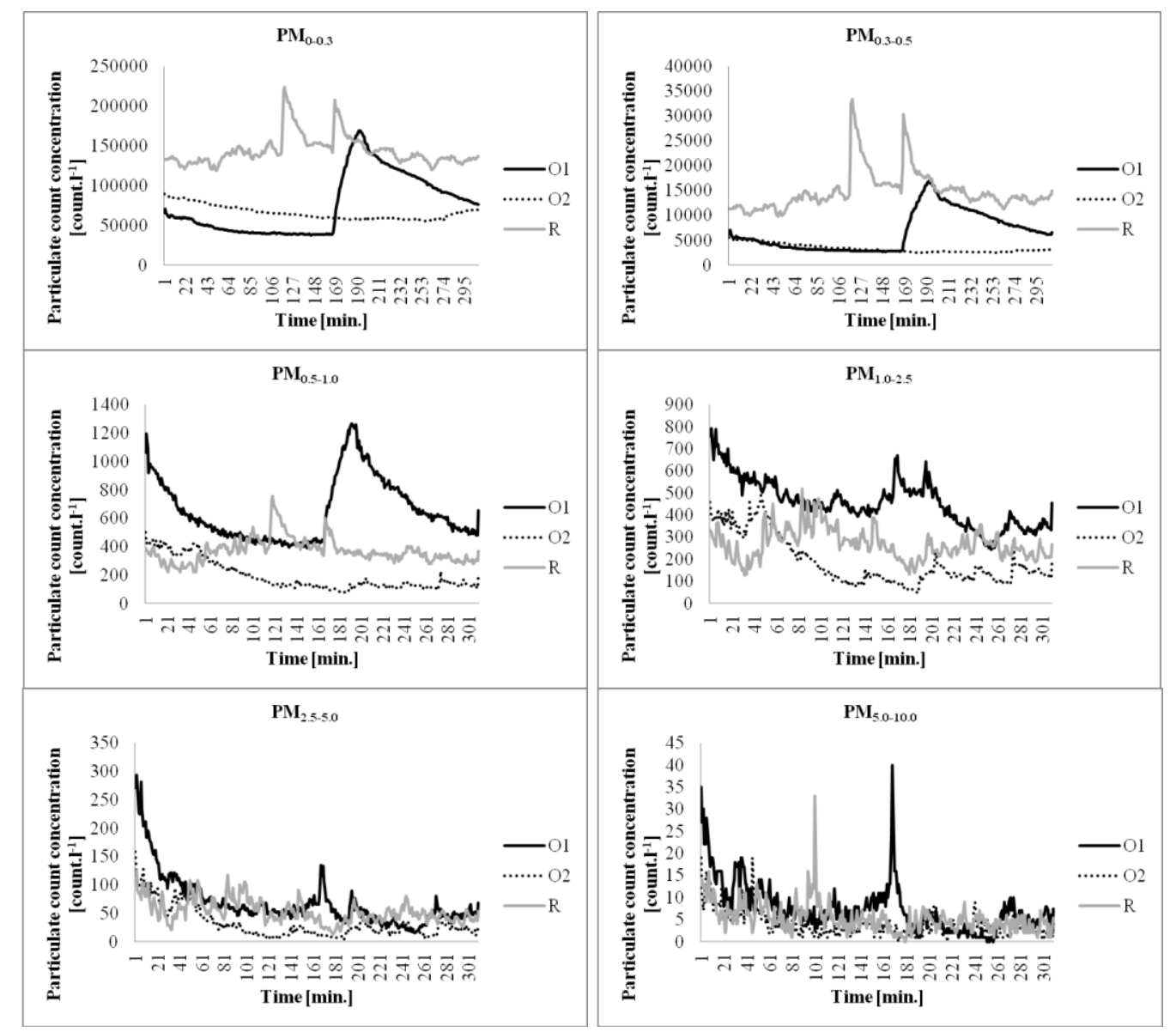

Figure 5: Course of particulate number concentrations for each fraction

TVOCs values represent the amount of various identified and non-identified compounds and were expressed as toluene equivalents. In office $\mathrm{O} 1$ the maximum concentration of TVOC reached value of $182 \mu \mathrm{g} \cdot \mathrm{m}^{-3}$ and average value was $139 \mu \mathrm{g} \cdot \mathrm{m}^{-3}$. In office $\mathrm{O} 2$ the maximum concentration of TVOC reached value of $180 \mu \mathrm{g} \cdot \mathrm{m}^{-3}$ and average value was $113 \mu \mathrm{g} \cdot \mathrm{m}^{-3}$. In 
reception $\mathrm{R}$ the maximum concentration of TVOC reached value of $145 \mu \mathrm{g} . \mathrm{m}^{-3}$ and average value was $112 \mu \mathrm{g} . \mathrm{m}^{-3}$. Courses of TVOC in office spaces are illustrated in Figure 3. After opening the windows, the concentrations of TVOC were decreased. The values were in line with those found in other studies; however, taking into account the guideline value of 200 $\mu \mathrm{g} . \mathrm{m}^{-3}$ suggested by Molhave [17].

Subjective air quality perception was significantly related to indoor environmental conditions such as temperature and $\mathrm{CO}_{2}$ levels, higher concentrations of particulates $\left(\mathrm{PM}_{10}\right)$ and exposure to high volatile organic compounds levels.

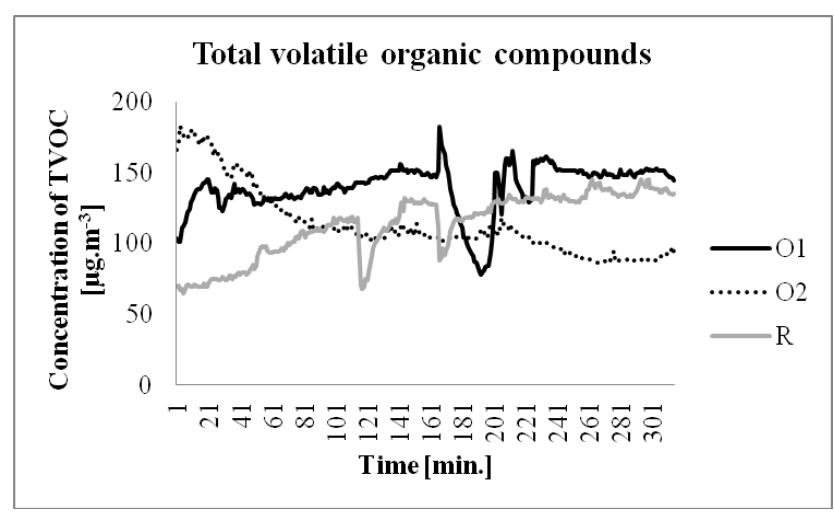

Figure 3: Course of total volatile organic compounds concentrations in monitored rooms

Results show, that indoor air temperature and indoor air quality were rated similarly, as slight discomfort (25\%) and discomfort (75\%). Indoor air humidity level was evaluated as comfort state $(50 \%)$ and slight discomfort state $(50 \%)$. The noise and lighting levels were evaluated as comfort state, as shown in Figure 6.

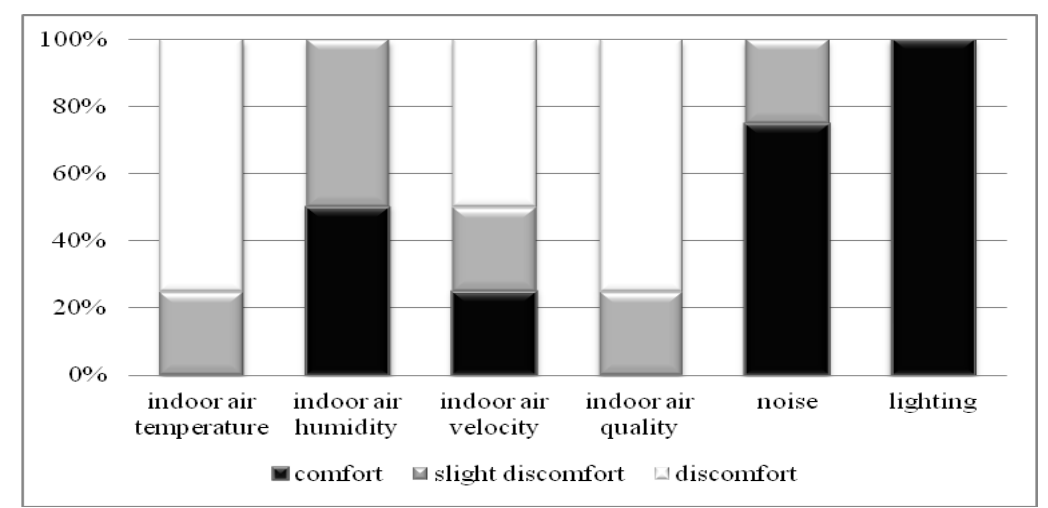

Figure 6: Summary of occupants' sensational evaluation of environmental parameters

In Figures 7 and 8 are summarized the impacts on perceived productivity of occupants that were assessed in office building. Indoor environmental parameters that influenced occupants' productivity at their workplace are presented in Figure 7. Indoor air temperature was rated as greatly increased $(50 \%)$, slight increased $(25 \%)$ and slight decreased $(25 \%)$. Indoor air humidity was rated as greatly increased (25\%), slight increased $(50 \%)$ and neutral $(25 \%)$. The airflow (air velocity) had greatly decreasing (50\%) effect on perceived productivity. The 
effects of indoor air quality and noise on occupants' productivity were assessed similarly. Results show that lighting had positive effect on perceived productivity (greatly increase $50 \%$, increase $-25 \%$ and neutral effect $-25 \%$ ). Figure 8 shows the impact of other factors on occupant' productivity. Visual contact with exterior and contact with nature from exterior and interior had similar effect on perceived productivity. The occupants rated other factors as positive or neutral, these factors increase perceived productivity.

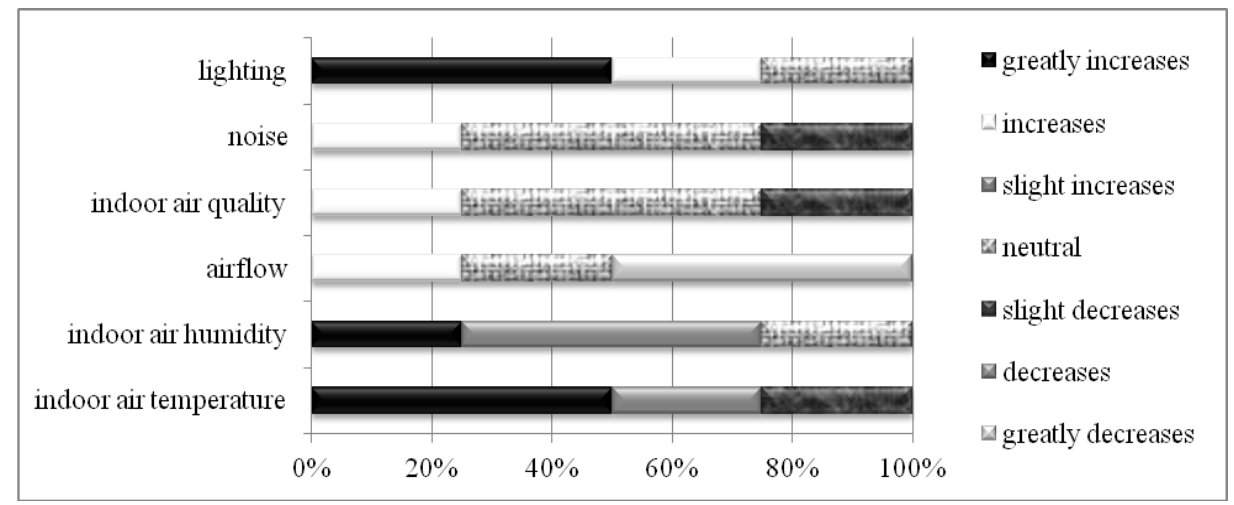

Figure 7: The impact of environmental parameters on perceived productivity of occupants

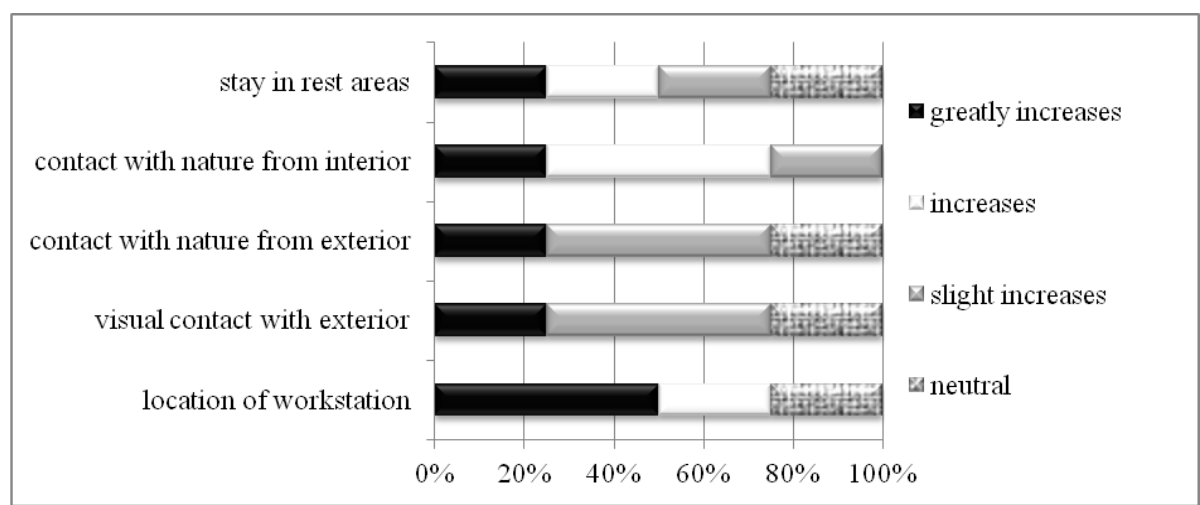

Figure 8: The impact of other factors on perceived productivity of occupants

Occupants performed three different office tasks to evaluate objective productivity:

- text typing,

- mathematical task - addition task,

- learning memory test - symbol-letter modalities test.

These are typical office tasks requiring concentration and in previous studie were shown to be sensitive to changes in air quality [18].

Objective productivity was evaluated using the following indicators:

- Total productivity (\%) - expressed as ratio of total number of solved answers to maximum number of answers.

- Correct productivity (\%) - expressed as ratio of correctly solved answers to maximum number of answers.

The measurement results of occupants' productivity of individual tasks and all tasks are presented in Table 3. Occupants' productivity of learning memory test was the lowest, but in 
this task there were no mistakes. Occupants had the most mistakes in mathematical calculation (addition).

Table 3: Productivity of occupants in three different office tasks

\begin{tabular}{|l|c|c|}
\hline \multicolumn{1}{|c|}{ Office tasks } & Total productivity (\%) & Correct productivity (\%) \\
\hline Text typing & 93.2 & 92.9 \\
\hline Mathematical calculation & 100 & 95.7 \\
\hline Learning memory test & 85 & 85 \\
\hline All tasks & 92.7 & 91.2 \\
\hline
\end{tabular}

\section{Conclusion}

This study has discussed the satisfaction of occupants with their environment in a modern building where the indoor environment qualities are controlled in accordance with existing IEQ standards and guidelines.

The indoor microclimate influences not only the comfort but also the health of the occupants, and preserving the comfort parameters at the optimal values is the mission of the engineer for designing and operating of HVAC systems [6].

Mean values of $\mathrm{PM}_{10}$ concentrations were exceeded limit value in $\mathrm{O} 1$ about $62.8 \%$ and in $\mathrm{R}$ about $46.4 \%$. Other environmental parameters were met limit value during the experiment. $\mathrm{CO}_{2}$ and TVOC levels were met recommended concentrations [16, 17]; on the other hand, in subjective assessment occupants rated air temperature and air quality as discomfort state. Mean values of air velocity levels were fulfilled [14]; however indoor air velocity was rated as greatly decreasing effect on occupant' productivity. Occupants considered other factors as positive (increasing or neutral effect). Objective total productivity of occupants in simulated office tasks was higher than $92 \%$; correct productivity was lower. In the task marked as learning memory test were no mistakes.

Further research works will be focused on evaluation of statistically significant set of office buildings sample for understanding the relationship between IEQ and occupants' responses and productivity.

\section{Acknowledgements}

This work has been supported by Grant Agency of Slovak Republic to support of project VEGA No. $1 / 0405 / 13$.

\section{References}

[1] Kosonen, R., Tan, F. (2004). The effect of perceived indoor air quality on productivity loss. Energy and Buildings. Vol. 36(10), pp. 981-986.

[2] WHO/EURO (2000). The Right to Healthy Indoor Air. EUR/00/5020494, World Health Organization, Regional Office for Europe, Copenhagen.

[3] Bluyssen, P.M., de Oliveira Fernandes, E., Groes, L., Clausen, G., Fanger, P.O., Valbjørn, O., Bernhard, C.A., Roulet, C.A. (1996). European indoor air quality audit project in 56 office buildings. Indoor Air. Vol. 6 (4), pp. 221-238. 
[4] Pejtersen, J., Schwab, R., Mayer, E. (1999). Sensory evaluation of the air in 14 office buildingspart of an interdisciplinary SBS study in Germany. Proceedings of Indoor Air 99, The 8th International Conference on Indoor Air Quality and Climate. Vol. 5, Edinburgh, pp. 390-395.

[5] Boyce, P., Hunter, C., Howlett, O. (2003). The benefits of daylight through windows. Troy, New York: Rensselaer Polytechnic Institute.

[6] Galasiu, A.D., Veitch, J.A. (2006). Occupant preferences and satisfaction with the luminous environment and control systems in daylit offices: a literature review. Energy Build 2006. Vol. 38 (7), pp.728 - 42 .

[7] Pellerin, N., Candas, V. (2003). Combined effects of temperature and noise on human discomfort. Physiology \& Behavior, Vol. 78 (1), pp. 99-106.

[8] Gunnarsen, L., Santos, A.M.B. (1998). Relative importance of temperature, draft, noise and windows area in office, Proceedings of the Second European Conference on Energy Performance and Indoor Climate in Buildings. Lyon, France, Ecole Nationale des Travaux Publics de l'Etat, Lyon, pp. 862-867.

[9] Sarbu, I., Sebarchievici, C. (2013). Aspects of indoor environmental quality assessment in buildings. Energy and Buildings. Vol. 60, pp. 410-419.

[10] Upadhaya, B., Munir, R., Blount, Y. (2014). Association between Performance Measurement Systems and Organisational Effectiveness. International Journal of Operations \& Production Management. Vol. 34(7), pp. 853-875.

[11] Antikainen, R., Lappalainen, S., Lonnqvist, A., Maksimainen, K., Reijula, K., Uusi-Rauva, E. (2008). Exploring the relationship between indoor air and productivity. Scandinavian Journal of Work Environment and Health. Vol. 34(4), pp. 79-82.

[12] Toftum, J., Wyon, D.P., Svanekjaer, H. and Lantner, A. (2005). Remote performance measurement (RPM) - A new, internet-based method for the measurement of occupant performance in office buildings. Indoor Air, 10th International Conference on Indoor Air Quality and Climate, Beijing, China, Vol. 1, pp. 357-361.

[13] Pilipova I., Vilčekova S. (2013). Perceived Comfort of Indoor Environment and Users' Performance in Office Building with Smart Elements -case Study. SSP-Journal of civil engineering. Vol. 8(2), pp. 61-72.

[14] Decree of the Ministry of Health of the Slovak Republic No. 259/2008 Coll. on details on requirements for interior environment of buildings and on minimum requirements for apartments of lower standard and for accommodation facilities. (in Slovak)

[15] Government Ordinance SR No. 115/2006 Coll. on minimum health and safety requirements for the protection of workers against the risks relating to noise exposition, as amended by SR government ordinance 555/2006 Coll. (in Slovak)

[16] Von Pettenkofer M. (1858). Über den Luftwechsel in Wohngebäuden. Cotta.

[17] Molhave, L. (1991). Volatile organic compounds, indoor air quality and health. Indoor Air. Vol. 1 (4), pp.357-376.

[18] Wargocki, P., Lagercrantz, L., Witterseh, T., Sundell, J., Wyon, D.P., Fanger, P.O. (2002). Subjective perceptions, symptom intensity and performance: a comparison of two independent studies, both changing similarly the pollution load in an office. Indoor air 2002. Vol. 12, pp. 7480 . 